\title{
SENSITIVITY OF ARBUSCULAR MYCORRHIZAL FUNGI IN OLD-GROWTH FORESTS: DIRECT EFFECT ON GROWTH AND SOIL CARBON STORAGE
}

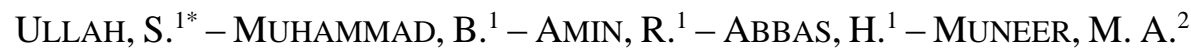 \\ ${ }^{I}$ College of Forestry, Beijing Forestry University, Beijing 100083, China \\ ${ }^{2}$ College of Grassland Science, Beijing Forestry University, Beijing 100083, China \\ *Corresponding author \\ e-mail: Saifkhan@bjfu.edu.cn, saif.haryankot@outlook.com; phone: +86-188-1079-7267
}

(Received $1^{\text {st }}$ May 2019; accepted $11^{\text {th }}$ Jul 2019)

\begin{abstract}
Arbuscular mycorrhizal association is ubiquitous and can be found in majority of natural habitats. Arbuscular mycorrhizal fungi (AMF) play a key role in the absorption of plant nutrients, soil aggregation and fertility. The basic role of AMF in the plant growth is to increase the absorption and translocation of relatively immobile ions and elements. In the past, studies have focused primarily on the mycorrhiza development and their general role in the growth of plants. Here, in this review manuscript, we highlight the role of AMF in the growth of old forests. In many studies, it has been found that concentration of phosphorous $(\mathrm{P})$ decreases with the stand age which as a result leads to phosphorous $(\mathrm{P})$ deficiency. This phosphorous $(\mathrm{P})$ deficiency is considered as a cause of slow growth of old forests. In this review article, we argued that apart from the low concentration of phosphorous $(\mathrm{P})$, weak arbuscular mycorrhizal associations are also a cause of slow growth of old forests. Furthermore, we also highlight the ecological role of AMF in the soil carbon storage. AMF provide physical (hyphae frame) and chemical support (Glomalin) to the dispersed soil particles to create stable aggregated soil structure. The Glomalin compound which is released by AMF acts like a glue and consequently increases soil aggregation. The soil organic matters stored in soil aggregates are less exposed to decomposition. Hence, soil can be used as a large sink where a huge amount of carbon can be stored in the form of soil organic matters which as a result can contribute to the mitigation of global climate change.
\end{abstract}

Keywords: spore germination, Glomalin, phosphorous $(P)$, heavy metals, soil aggregation

\section{Introduction}

The permanency and functioning of a terrestrial ecosystem are determined by plant biodiversity and species composition (Bond et al., 1993; Tilman and Downing, 1994; Naeem et al., 1994; Tilman et al., 1996; Hooper and Vitousek, 1997; Wang et al., 2006, 2008). The collaboration between aboveground and belowground mechanisms in all terrestrial ecosystems impacts community and ecosystem-level processes (Wardle et al., 2004). Typically, in a terrestrial ecosystem, different mycorrhizal symbiotic links develop between plants and fungi in an extensive range (Finlay, 2008). These symbiotic associations are abundant and occur in 75 to $80 \%$ plants (Clasen et al., 2018). Mycorrhizal association plays very important role in ecosystem which improves plants growth and existence through a mutualistic relationship (Kernaghan, 2005) as can be seen in Figure 1. There is a give-and-take influence or "feedback" between plants and mycorrhizal fungi. For instance, the diversity of mycorrhiza promotes several plants community traits which in turn can promote mycorrhizal diversity (Castelli and Casper, 2003; Reynolds et al., 2003).

The term 'Mycorrhiza' was first used in 1885 by Frank to define the modified root structures of forest trees (Frank, 2005). In the mycorrhizal associations, arbuscular 
mycorrhizal fungi (AMF) is the result of the mutual adaptation of plants and fungi (Smith and Smith, 1990). AMF symbiosis is one of the oldest association on ground and hired in to the phylum Glomeromycota and order Glomales (Smith and Read, 1997; Schüßler, 2002).

In terrestrial ecosystem, AMF is the essential component (Smith and Read, 2008) and can be found in many herbaceous plant communities in abundance (Allen et al., 1995; Kennedy et al., 2005). Generally, the distribution of AMF species is dependent on many factors, for instance, environmental conditions and host plant species (Koske, 1981; Hetrick and Bloom, 1986). Hence, richness and diversity of AMF vary across different community types (Gai et al., 2009).

Previous studies have focused primarily on the mycorrhiza development and their general role in the growth of plants. Here, in this review manuscript, we highlight the role of AMF in the growth of old forests. In many studies, it has been found that concentration of phosphorous $(\mathrm{P})$ decreases with stand age which as a result leads to phosphorous (P) deficiency (Jiao et al., 2013; Li et al., 2013). This phosphorous (P) deficiency is considered as a cause of slow growth of old forests. In this review article, we argue that apart from the low concentration of phosphorus, weak Arbuscular mycorrhizal associations are also a cause of the slow growth. We suggest that the growth of old forests can be made better if suitable environment for the germination and development of arbuscular mycorrhizal fungi (AMF) associations is provided which as a result can increase above ground biomass. Furthermore, we considered a portion on the ecological role of AMF in the soil carbon storage. The Glomalin compound which is released by AMF plays a very important role in the soil aggregation. The soil organic matters stored in soil aggregates are less exposed to decomposition. In this study, we highlight the importance of soil as a large sink where a huge amount of carbon can be stored in the form of soil organic matters which as a result can mitigate the problem of global climate change.

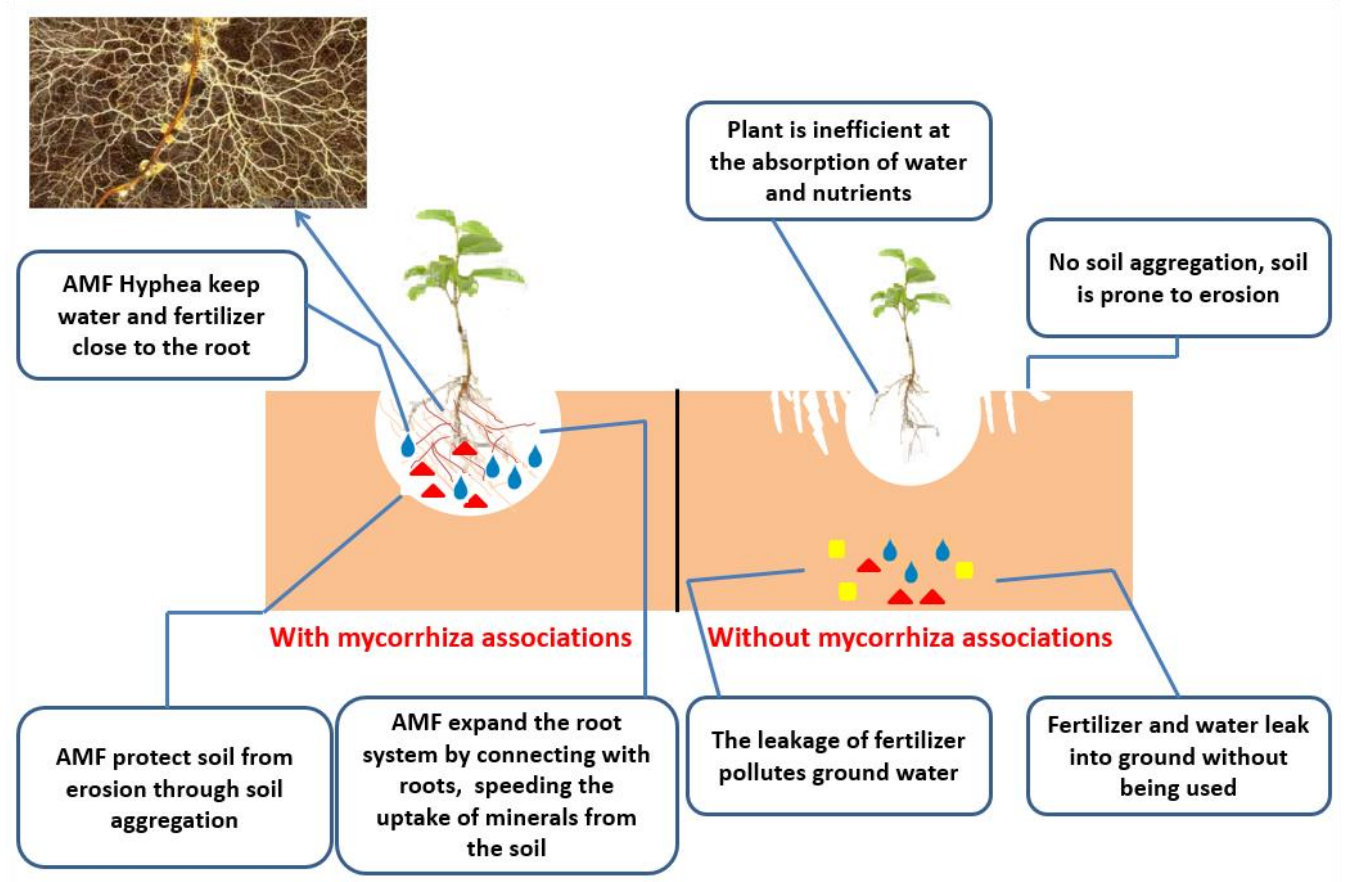

Figure 1. Mycorrhiza associations play a key role in the growth of a plant 


\section{Role of AMF in forest growth}

The main role of AMF is to increase the absorption and translocation of relatively immobile ions and elements (Cooper and Tinker, 1981; Liu et al., 2000). These immobile ions (phosphate, ammonium and nitrate) and elements (such as $\mathrm{P}, \mathrm{Zn}, \mathrm{Ca}, \mathrm{S}$ and $\mathrm{N}$ ) are translocated through hyphae of AMF. In return, AMF receive carbon from the plant in the form of photosynthates (Fig. 2). About 5 to $10 \%$ of plants taken carbon during photosynthesis is usually released to the soil via roots (Farrar et al., 2003; Zhang et al., 2016).

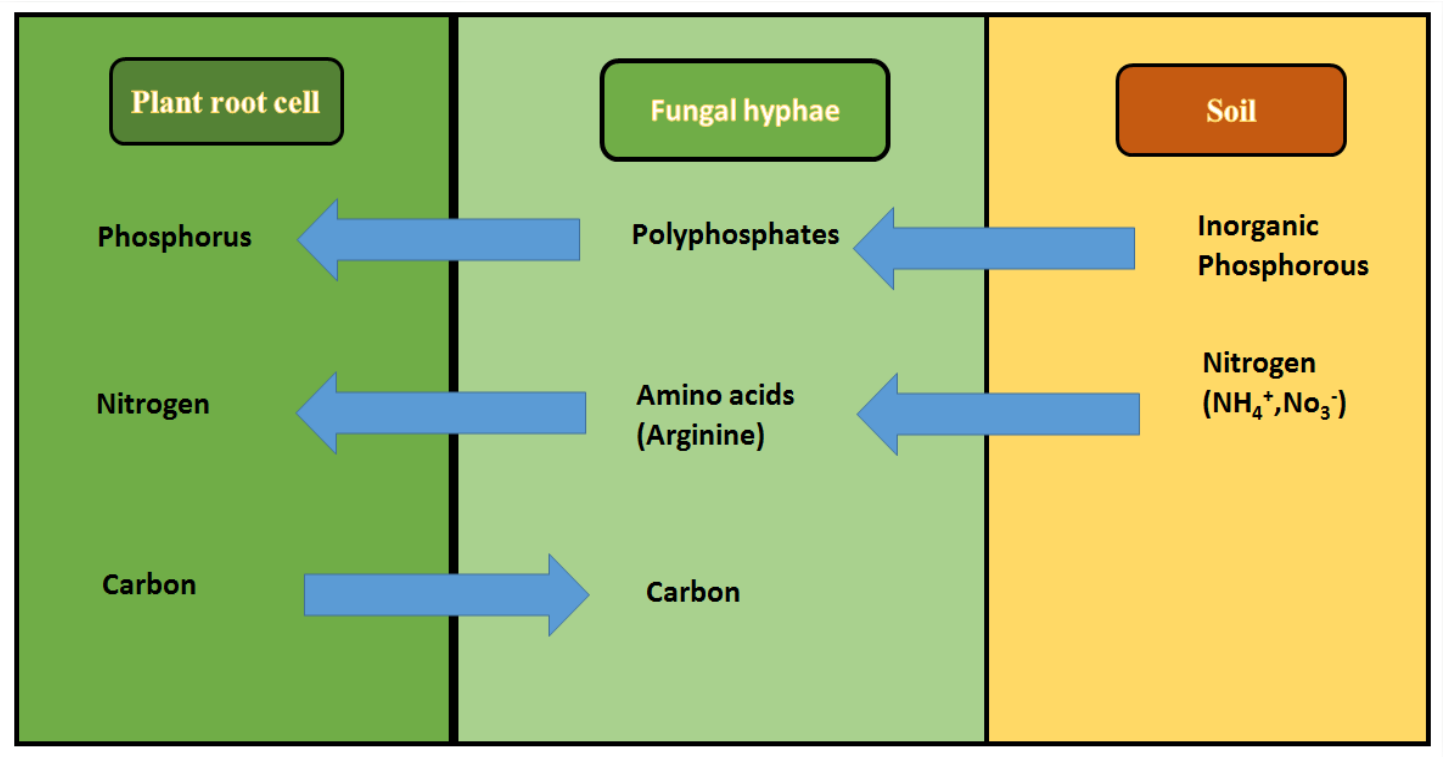

Figure 2. Mutual nutrient supply between plant and AMF hyphae (Selosse and Rousset, 2011)

Among AMF translocated immobile elements, phosphorous $(\mathrm{P})$ is considered one of the primary nutrients for plant growth (Hinsinger, 2001). In soil, phosphorous (P) usually present in both organic and inorganic forms. Majority of it is in insoluble form as in acid soil, phosphate ions are mostly adsorbed in the form of $\mathrm{Fe}$ and $\mathrm{Al}$ phosphates, while in alkaline and calcareous soils, it is adsorbed in the form of $\mathrm{Ca}$ and $\mathrm{Mg}$ phosphates (Mehrotra, 2005). As already mentioned, AMF plays a very important role in the uptaking of these phosphorous (P) immobile ions (Cooper and Tinker, 1981; Liu et al., 2000). It is found that AMF is more efficient than plant roots at up-taking of phosphorous (P). The rate of up-taking can be six times faster than root hairs (Bolan, 1991). The uptaking phosphorous $(\mathrm{P})$ is needed to maintain optimum plant quality, cell division, plant metabolisms, reproduction and energy storage (Zapata and Zaharah, 2002; Epstein, 1972). Moreover, phosphorous (P) plays an important role in the availability of nutrients, root development, root morphology and its branching (López-Bucio et al., 2003; Jin et al., 2005). The deficiency of phosphorous $(\mathrm{P})$ usually leads to undersized, necrotic and erect leaves, lateral buds and subnormal root development. Hence, the availability of phosphorous $(\mathrm{P})$ is very important for the growth of forest and it has been found that the growth of some regions is more effected by Phosphorous $(\mathrm{P})$ than Nitrogen (N) (Jiao et al., 2013). The reason behind it is that AMF do not directly increase the up-taking of nitrogen but actually help plant in absorbing phosphorus which as a result also affects the absorption of other nutrients such as nitrogen (Mehrotra, 2005). 
As stated earlier, the concentration of phosphorous $(\mathrm{P})$ does not remain the same with the stand age and it decreases with the passage of time from early successional stage to late successional stage ( $\mathrm{Li}$ et al., 2013; Jiao et al., 2013). As a result, many old forests with phosphorous $(\mathrm{P})$ deficiency, have less growth, productivity and less carbon biomass. Here we propose that phosphorous $(\mathrm{P})$ deficiency is not the only reason behind the slow growth of old forests. There are other factors which are accounted for the slow growth such as AMF spore germination and spore density. In a forest, AMF spore germination and AMF spore density are directly connected to the up-taking of phosphorous $(\mathrm{P})$ which means that less spore germination and less spore density result in the decrease of phosphorous (P) absorption which is the case for an old forest. There are many factors which affect spore germination and spore density such as plant cover, soil sampling depth, soil fertility, seasonal variations, altitudinal gradient, soil moister, $\mathrm{PH}$, and heavy metals concentration (Hepper and Smith, 1976; Jansa et al., 2005; Weissenhorn et al., 1993; He et al., 2002; Pawlowska and Charvat, 2004a). But here we discuss only three factors, e.g. heavy metals concentrations, soil fertility and plant cover which can be important in the context of old growth forests. The first factor, heavy metal concentration affects the initial stage of spore germination of AMF. It has been found that from early successional stage to late successional stage, the concentrations of heavy metals ( $\mathrm{Zn}, \mathrm{Fe}$, $\mathrm{Cu}$ ) increases which has negative impact on the initial stage of AMF spore germination (Li et al., 2013; Jiao et al., 2013; Pawlowska and Charvat, 2004b). The other two factors are related to spore density. Generally, increase in the concentration of different elements (e.g. N. Ca, K, and Mn) with stand age indicates increase in the fertility. It is well known that AMF possess higher spores density in low fertile soil due to slower decomposition rates and longer lived roots which is not the case for old forests (Eissenstat and Yanai, 1997; Zak and Pregitzer, 1998; Lovelock et al., 2003; Nadelhoffer, 2000). On other hand, plant cover which increases with the stand age of a forest negatively affects the spore density (He et al., 2002). Spore density and spore germination are crucial stages for AMF occurrence, distribution and colonization which play important role to provide phosphorous (P) for growth. Hence, apart from the phosphorous $(\mathrm{P})$ deficiency, increase in the heavy metals concentration, fertility and plant cover also affect the growth of old forests through weak arbuscular mycorrhizal associations. Hence, we claim that the growth of old forests can be made better if suitable environment for the germination and development of arbuscular mycorrhizal fungi (AMF) associations is provided.

Here, we suggest that the development of rich food sites (like grasslands) around the boundaries of old forests can improve the distribution and density of AMF spores inside the old forests. The food sites will attract mammals, rodents, ungulates, migratory and local birds (endozochoorous co-dispersers, transfer usable propagules of both mutual associates-plants and AM fungi) (Bueno and Moora, 2019) that can spread spores of arbuscular mycorrhiza through bird droppings and faeces in old forests. In addition, the use of information and communication technology (ICT) for the management of old forests can improve plant community structure, ecosystem health, biodiversity and above ground biomass.

\section{Role of AMF in soil carbon storage}

Globally, forest soil contains approximately half of the earth terrestrial carbon $(1146 \times 1015 \mathrm{~g})$ and about two-thirds of this amount is retained in soil pools (Dixon et al., 1994; Goodale et al., 2002). Understanding of the mechanisms through which we 
can control soil carbon storage is crucial for the climate change (Averill et al., 2014). The soil organic carbon pool is an important regulator of the carbon exchange between biosphere and atmosphere. In order to achieve carbon loss-gain balance and mitigate global climate change, the soil carbon storage should be increased (Díaz et al., 2009). Soil carbon storage is directly related to the microbial community contribution, dynamics, biomass, balance between formation and degradation of microbial byproducts and indirectly related with carbon cycling and soil aggregation (Six et al., 2006). To increase the storage capacity of the soil for carbon, the role of AMF cannot be ignored. As can be seen from Figure 2, the transfer of carbon from the host plant to AMF hyphae occurs in the form of photosynthates. This transfer usually takes place within few hours (Johnson et al., 2002). It has been found that the presence of mycorrhizal associations increases significantly plant carbon assimilation during photosynthesis (Miller et al., 2002; Grimoldi et al., 2006; Calderón et al., 2012) and as a result can increase carbon induction into soil (Grimoldi et al., 2006). AMF take carbon from the host plant in exchange for phosphorous (P) to expand the hyphae network. Generally a large fraction of soil carbon is labile and can readily undergo changes and decomposition if exposed to high moisture and temperature (Davidson and Janssens, 2006). Any significant increase in the decomposition of soil organic matter (SOM) can make the problem of global climate change severe. So we need to protect this soil organic matter from decomposition and as result we can dump more and more carbon inside soil in the form of SOM. This can be done if we store SOM in soil aggregates. In soil aggregation, insoluble Glomalin glycoprotein produced by AMF hyphae and spore plays very important role (Driver et al., 2005; Gonzalez-Chavez et al., 2004). The hyphae which behave like wall boards and soil particles which behave like insulation fills spaces between these boards (hyphae). The Glomalin covers it like a protective layer of paint on a wall (Fig. 3). Glomalin is very important for the stability of these soil aggregates. In the case of weak aggregation, aggregates can easily eroded by rainfall and all the organic matter and nutrients stored in these aggregates will be lost.

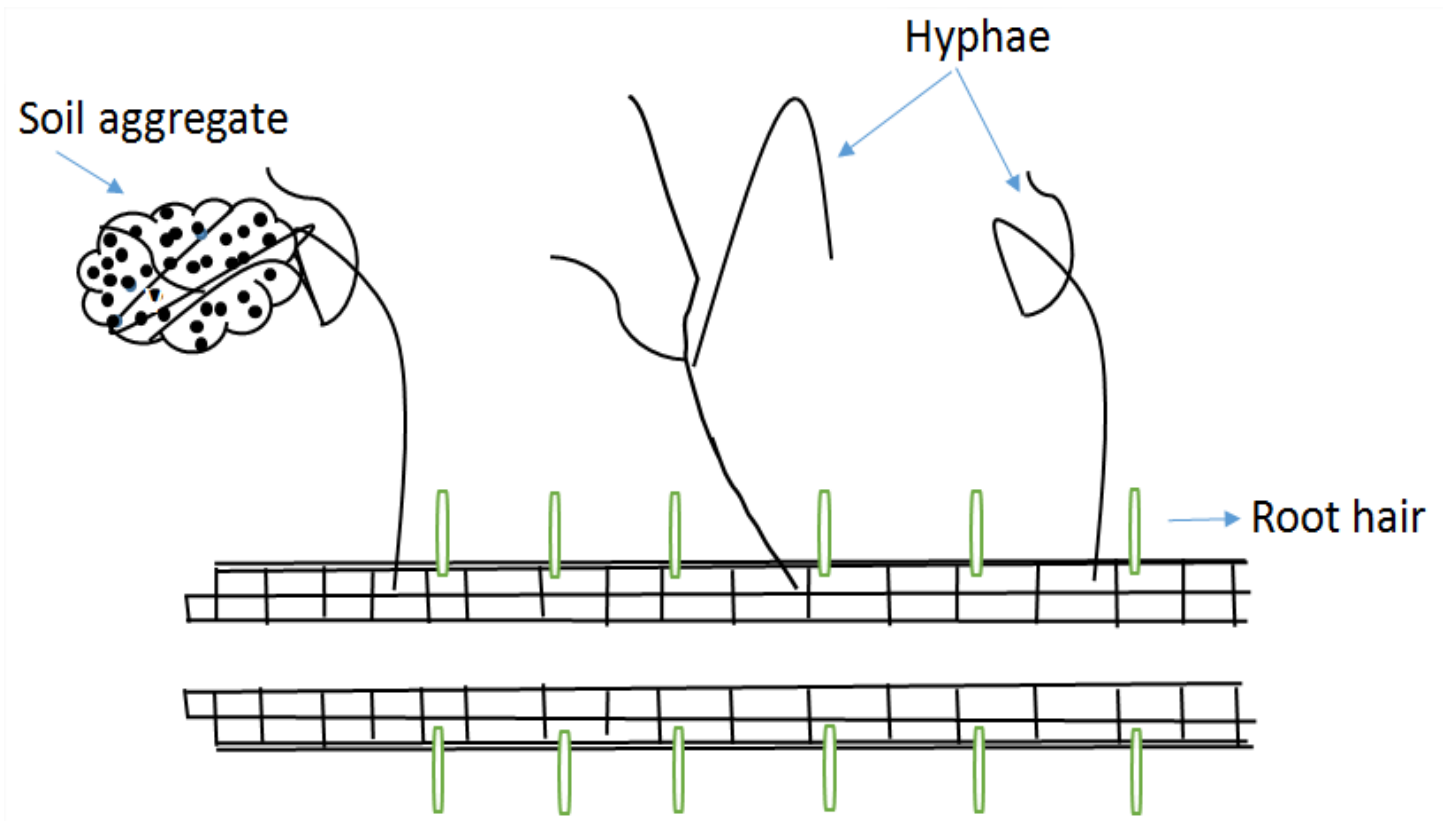

Figure 3. Hyphae collect soil particles and then coat it with Glomalin to form soil aggregates (Rillig, 2004) 
Glomalin for the first time was discovered by soil scientist Sara F. Wright of the United States Department of Agriculture (USDA) and Agricultural Research Service (ARS) in 1996 (Wright and Upadhyaya, 1996). Glomalin is a compound which is not soluble in water and also resistant to heat degradation. Glomalin is still not defined biochemically. It consists of 4 to 6\% Hydrogen, 33 to $49 \%$ Oxygen, 36 to 59\% Carbon, $3-5 \%$ Nitrogen and 0.03 to $0.1 \%$ Phosphorus. Glomalin has reddish color and it is because of the 0.8 to $8.8 \%$ of Iron. This range of Iron concentration makes Glomalin resistive to degradation, increases thermal stability and strengthens Glomalin antimicrobial properties (Fokom et al., 2012).

As already explained, AMF especially Vesicular Arbuscular Mycorrhizal (VAM) is very important for the growth of a plant because of the hyphae hair like projections which can explore soil better than plant roots for different nutrients. Fungus supply different nutrients especially Phosphorus to the plant and in return plant provides carbon to the fungus for the growth. The excreted Glomalin covers the hyphae with hydrophobic sheet to stop any leakage of nutrients. When the roots grow and hyphae stop supply of nutrients, the Glomalin is generally released to the soil where it sticks to the organic materials and minerals. In soil, its presence increases soil aggregation and because of its ability to protect organic matters inside aggregates, it is also associated with carbon sequestration (Rillig et al., 1999). Functions of Glomalin can be summarized as:

- Acts like glue and helps in soil aggregation (Wright and Upadhyaya, 1998)

- Mitigates water and soil erosion (Andrade et al., 1998)

- Increases percolation of water (Prasad et al., 2018)

- Increases retention of water close to the roots (Bitterlich et al., 2018)

- Makes improvements to the recycling of nutrients (Singh, 2012)

- Improves carbon and nitrogen storage (Ariza et al., 2008)

\section{Summary and future perspectives}

To summarize, we have reviewed the role of AMF in the growth of old forests. Previously, researchers have found that low concentration of phosphorous $(\mathrm{P})$ is the main cause of the slow growth of old forests. In this review article, we argued that apart from the low concentration of phosphorus, weak Arbuscular mycorrhizal association is also a cause of the slow growth. In old growth forests, the concentration of heavy metals has increased with the stand age which negatively affects the initial germination stage of AMF spores. Furthermore, an increase in fertility and plants cover with stand-age also decreased AMF spore density. These all factors over all affected the AMF associations in the old forests. Thus we claim that the growth of old forests can be improved provided that spore germination and spore density are increased which as a result can increase above ground biomass. In this study, we suggested that the development of rich food sites (like grasslands) around the boundaries of old forests can improve the distribution and density of AMF spores inside the old forests. The food sites will attract mammals, rodents, ungulates, migratory and local birds (endozochoorous co-dispersers, transfer usable propagules of both mutual associates-plants and AM fungi) that can spread spores of arbuscular mycorrhiza through bird droppings and faeces in the old forests. In addition, the use of information and communication technology (ICT) for the management of old forests can improve plant community structure, ecosystem health, biodiversity and above ground biomass. Apart from the role of AMF in the old forests, 
we also highlighted the importance of AMF in soil aggregation. The Glomalin compound which is released by AMF (spores and hyphae) acts like glue and consequently increase soil aggregation. The soil organic matters stored in soil aggregates are less exposed to decomposition. Hence, soil can be used as a large sink where a huge amount of carbon can be stored in the form of soil organic matters which as result can mitigate the problem of global climate change.

Acknowledgements. We are grateful to all referees for their comments and suggestions which have improved our article a lot. We would also like to thank Prof. XiangPing Wang and Dr. Arif Ullah for their valuable discussion and suggestions. This study was supported by the National Key Research and Development Program of China (\#2017YFC0503901) and National Natural Science Foundation of China (31870430).

\section{REFERENCES}

[1] Allen, E. B., Allen, M. F., Helm, D. J., Trappe, J. M., Molina, R., Rincon, E. (1995): Patterns and regulation of mycorrhizal plant and fungal diversity. - Plant and Soil 170(1): 47-62.

[2] Ariza, M., Boutton, T., Gonzalez Chavez, M. d. C., Filley, T. (2008): Carbon and nitrogen storage in glomalin-related soil protein during grassland-to-woodland succession. - American Geophysical Union Abstract B23B-0412.

[3] Averill, C., Turner, B. L., Finzi, A. C. (2014): Mycorrhiza-mediated competition between plants and decomposers drives soil carbon storage. - Nature 505(7484): 543.

[4] Bitterlich, M., Franken, P., Graefe, J. (2018): Arbuscular mycorrhiza improves substrate hydraulic conductivity in the plant available moisture range under root growth exclusion. - Frontiers in Plant Science 9(301). DOI: 10.3389/fpls.2018.00301.

[5] Bolan, N. (1991): A critical review on the role of mycorrhizal fungi in the uptake of phosphorus by plants. - Plant and Soil 134(2): 189-207.

[6] Bond, W., Schulze, E., Mooney, H. (1993): Biodiversity and Ecosystem Function. Springer-Verlag, Berlin.

[7] Bueno, G., Moora, M. (2019): Commentary. How do arbuscular mycorrhizal fungi travel? - New Phytologist 222(2): 645-647. DOI: 10.1111/nph.15722.

[8] Calderón, F. J., Schultz, D. J., Paul, E. A. (2012): Carbon allocation, belowground transfers, and lipid turnover in a plant-microbial association. - Soil Science Society of America Journal 76(5): 1614-1623.

[9] Castelli, J. P., Casper, B. B. (2003): Intraspecific AM fungal variation contributes to plant-fungal feedback in a serpentine grassland. - Ecology 84(2): 323-336.

[10] Clasen, B. E., Silveira, A. d. O., Baldoni, D. B., Montagner, D. F., Jacques, R. J. S., Antoniolli, Z. I. (2018): Characterization of ectomycorrhizal species through molecular biology tools and morphotyping. - Scientia Agricola 75(3): 246-254.

[11] Cooper, K. M., Tinker, P. (1981): Translocation and transfer of nutrients in vesicular-arbuscular mycorrhizas: IV. Effect of environmental variables on movement of phosphorus. - New Phytologist 88(2): 327-339.

[12] Davidson, E. A., Janssens, I. A. (2006): Temperature sensitivity of soil carbon decomposition and feedbacks to climate change. - Nature 440(7081): 165.

[13] Díaz, S., Hector, A., Wardle, D. A. (2009): Biodiversity in forest carbon sequestration initiatives: not just a side benefit. - Current Opinion in Environmental Sustainability 1(1): $55-60$.

[14] Dixon, R. K., Solomon, A., Brown, S., Houghton, R., Trexier, M., Wisniewski, J. (1994): Carbon pools and flux of global forest ecosystems. - Science 263(5144): 185-190. 
[15] Driver, J. D., Holben, W. E., Rillig, M. C. (2005): Characterization of glomalin as a hyphal wall component of arbuscular mycorrhizal fungi. - Soil Biology and Biochemistry 37(1): 101-106.

[16] Eissenstat, D., Yanai, R. (1997): The ecology of root lifespan. - Advances in Ecological Research 27: 1-60.

[17] Epstein, E. (1972): Mineral Nutrition of Plants: Principles and Perspectives. - John Wiley and Sons New York.

[18] Farrar, J., Hawes, M., Jones, D., Lindow, S. (2003): How roots control the flux of carbon to the rhizosphere. - Ecology 84(4): 827-837.

[19] Finlay, R. D. (2008): Ecological aspects of mycorrhizal symbiosis: with special emphasis on the functional diversity of interactions involving the extraradical mycelium. - Journal of Experimental Botany 59(5): 1115-1126.

[20] Fokom, R., Adamou, S., Teugwa, M., Boyogueno, A. B., Nana, W., Ngonkeu, M., Tchameni, N., Nwaga, D., Ndzomo, G. T., Zollo, P. A. (2012): Glomalin related soil protein, carbon, nitrogen and soil aggregate stability as affected by land use variation in the humid forest zone of south Cameroon. - Soil and Tillage Research 120: 69-75.

[21] Frank, B. (2005): On the nutritional dependence of certain trees on root symbiosis with belowground fungi (an English translation of AB Frank's classic paper of 1885). Mycorrhiza 15(4): 267-275.

[22] Gai, J., Christie, P., Cai, X., Fan, J., Zhang, J., Feng, G., Li, X. (2009): Occurrence and distribution of arbuscular mycorrhizal fungal species in three types of grassland community of the Tibetan Plateau. - Ecological Research 24(6): 1345.

[23] Gonzalez-Chavez, M., Carrillo-Gonzalez, R., Wright, S., Nichols, K. (2004): The role of glomalin, a protein produced by arbuscular mycorrhizal fungi, in sequestering potentially toxic elements. - Environmental Pollution 130(3): 317-323.

[24] Goodale, C. L., Apps, M. J., Birdsey, R. A., Field, C. B., Heath, L. S., Houghton, R. A., Jenkins, J. C., Kohlmaier, G. H., Kurz, W., Liu, S. (2002): Forest carbon sinks in the Northern Hemisphere. - Ecological Applications 12(3): 891-899.

[25] Grimoldi, A. A., Kavanová, M., Lattanzi, F. A., Schäufele, R., Schnyder, H. (2006): Arbuscular mycorrhizal colonization on carbon economy in perennial ryegrass: quantification by $13 \mathrm{CO} 2 / 12 \mathrm{CO} 2$ steady-state labelling and gas exchange. - New Phytologist 172(3): 544-553.

[26] He, X., Mouratov, S., Steinberger, Y. (2002): Spatial distribution and colonization of arbuscular mycorrhizal fungi under the canopies of desert halophytes. - Arid Land Research and Management 16(2): 149-160.

[27] Hepper, C., Smith, G. (1976): Observation's on the germination of Endogone spores. Transactions of the British Mycological Society 66(2): 189-194.

[28] Hetrick, B. A. D., Bloom, J. (1986): The influence of host plant on production and colonization ability of vesicular-arbuscular mycorrhizal spores. - Mycologia 78(1): 3236.

[29] Hinsinger, P. (2001): Bioavailability of soil inorganic P in the rhizosphere as affected by root-induced chemical changes: a review. - Plant and Soil 237(2): 173-195.

[30] Hooper, D. U., Vitousek, P. M. (1997): The effects of plant composition and diversity on ecosystem processes. - Science 277(5330): 1302-1305.

[31] Jansa, J., Mozafar, A., Frossard, E. (2005): Phosphorus acquisition strategies within arbuscular mycorrhizal fungal community of a single field site. - Plant and Soil 276(1-2): 163-176.

[32] Jiao, F., Wen, Z.-M., An, S.-S., Yuan, Z. (2013): Successional changes in soil stoichiometry after land abandonment in Loess Plateau, China. - Ecological Engineering 58: 249-254.

[33] Jin, J., Wang, G., Liu, X., Pan, X., Herbert, S. J. (2005): Phosphorus application affects the soybean root response to water deficit at the initial flowering and full pod stages. Soil Science \& Plant Nutrition 51(7): 953-960. 
[34] Johnson, D., Leake, J., Read, D. (2002): Transfer of recent photosynthate into mycorrhizal mycelium of an upland grassland: short-term respiratory losses and accumulation of 14C. - Soil Biology and Biochemistry 34(10): 1521-1524.

[35] Kennedy, N., Edwards, S., Clipson, N. (2005): Soil bacterial and fungal community structure across a range of unimproved and semi-improved upland grasslands. Microbial Ecology 50(3): 463-473.

[36] Kernaghan, G. (2005): Mycorrhizal diversity: cause and effect. - Pedobiologia 49(6): 511-520.

[37] Koske, R. (1981): A preliminary study of interactions between species of vesiculararbuscular fungi in a sand dune. - Transactions of the British Mycological Society 76(3): 411-416.

[38] Li, Y., Yang, F., Ou, Y., Zhang, D., Liu, J., Chu, G., Zhang, Y., Otieno, D., Zhou, G. (2013): Changes in forest soil properties in different successional stages in lower tropical China. - PloS One 8(11): e81359.

[39] Liu, A., Hamel, C., Hamilton, R., Ma, B., Smith, D. (2000): Acquisition of Cu, Zn, Mn and Fe by mycorrhizal maize (Zea mays L.) grown in soil at different $\mathrm{P}$ and micronutrient levels. - Mycorrhiza 9(6): 331-336.

[40] López-Bucio, J., Cruz-Ramirez, A., Herrera-Estrella, L. (2003): The role of nutrient availability in regulating root architecture. - Current Opinion in Plant Biology 6(3): 280287.

[41] Lovelock, C. E., Andersen, K., Morton, J. B. (2003): Arbuscular mycorrhizal communities in tropical forests are affected by host tree species and environment. Oecologia 135(2): 268-279.

[42] Mehrotra, V. (2005): Mycorrhiza: Role and Applications. - Allied Publishers, New Delhi.

[43] Miller, R., Miller, S., Jastrow, J., Rivetta, C. (2002): Mycorrhizal mediated feedbacks influence net carbon gain and nutrient uptake in Andropogon gerardii. - New Phytologist 155(1): 149-162.

[44] Nadelhoffer, K. J. (2000): The potential effects of nitrogen deposition on fine-root production in forest ecosystems. - New Phytologist 147(1): 131-139.

[45] Naeem, S., Thompson, L. J., Lawler, S. P., Lawton, J. H., Woodfin, R. M. (1994): Declining biodiversity can alter the performance of ecosystems. - Nature 368(6473): 734737.

[46] Pawlowska, T. E., Charvat, I. (2004a): Heavy-metal stress and developmental patterns of arbuscular mycorrhizal fungi. - Applied and Environmental Microbiology 70(11): 66436649.

[47] Pawlowska, T. E., Charvat, I. (2004b): Heavy-metal stress and developmental patterns of arbuscular mycorrhizal fungi. - Appl. Environ. Microbiol 70(11): 6643-6649.

[48] Prasad, M., Chaudhary, M., Ramakrishnan, S. (2018): Glomalin: a miracle protein for soil sustainability. - Indian Farmer 5(09): 1092-1100.

[49] Reynolds, H. L., Packer, A., Bever, J. D., Clay, K. (2003): Grassroots ecology: plantmicrobe-soil interactions as drivers of plant community structure and dynamics. Ecology 84(9): 2281-2291.

[50] Rillig, M. C. (2004): Arbuscular mycorrhizae, glomalin, and soil aggregation. - Canadian Journal of Soil Science 84(4): 355-363.

[51] Rillig, M. C., Wright, S. F., Allen, M. F., Field, C. B. (1999): Rise in carbon dioxide changes soil structure. - Nature 400(6745): 628.

[52] Schüßler, A. (2002): Molecular Phylogeny, Taxonomy, and Evolution of Geosiphon Pyriformis and Arbuscular Mycorrhizal Fungi. - In: S. E. Smith, F. A. Smith (eds.) Diversity and Integration in Mycorrhizas. Springer, Dordrecht, pp. 75-83.

[53] Selosse, M.-A., Rousset, F. (2011): The plant-fungal marketplace. - Science 333(6044): 828-829.

[54] Singh, P. K. (2012): Role of glomalin related soil protein produced by arbuscular mycorrhizal fungi - a review. - Agric Sci Res J 2(3): 119-125. 
[55] Six, J., Frey, S., Thiet, R., Batten, K. (2006): Bacterial and fungal contributions to carbon sequestration in agroecosystems. - Soil Science Society of America Journal 70(2): 555569.

[56] Smith, S., Smith, F. (1990): Structure and function of the interfaces in biotrophic symbioses as they relate to nutrient transport. - New Phytologist 114(1): 1-38.

[57] Smith, S., Read, S. (1997): Mycorrhizal Symbiosis. 2nd Ed. - Academic Press, San Diego, CA.

[58] Smith, S., Read, D. (2008): Mycorrhizal Symbiosis. 3rd Ed. - Academic Press, San Diego, CA.

[59] Tilman, D., Downing, J. A. (1994): Biodiversity and stability in grasslands. - Nature 367(6461): 363.

[60] Tilman, D., Wedin, D., Knops, J. (1996): Productivity and sustainability influenced by biodiversity in grassland ecosystems. - Nature 379(6567): 718.

[61] Wang, X., Fang, J., Zhu, B. (2008): Forest biomass and root-shoot allocation in northeast China. - Forest Ecology and Management 255(12): 4007-4020.

[62] Wang, X. P., Tang, Z. Y., Fang, J. Y. (2006): Climatic control on forests and tree species distribution in the forest region of northeast China. - Journal of Integrative Plant Biology 48(7): 778-789.

[63] Wardle, D. A., Bardgett, R. D., Klironomos, J. N., Setälä, H., Van Der Putten, W. H., Wall, D. H. (2004): Ecological linkages between aboveground and belowground biota. Science 304(5677): 1629-1633.

[64] Weissenhorn, I., Leyval, C., Berthelin, J. (1993): Cd-tolerant arbuscular mycorrhizal (AM) fungi from heavy-metal polluted soils. - Plant and Soil 157(2): 247-256.

[65] Wright, S. F., Upadhyaya, A. (1996): Extraction of an abundant and unusual protein from soil and comparison with hyphal protein of arbuscular mycorrhizal fungi. - Soil Science 161(9): 575-586.

[66] Zak, D. R., Pregitzer, K. S. (1998): Integration of Ecophysiological and Biogeochemical Approaches to Ecosystem Dynamics. - In: Pace, M. L., Groffman, P. M. (eds.) Successes, Limitations, and Frontiers in Ecosystem Science. - Springer, New York, pp. 372-403.

[67] Zapata, F., Zaharah, A. (2002): Phosphorus availability from phosphate rock and sewage sludge as influenced by the addition of water soluble phosphate fertilizer. - Nutrient Cycling in Agroecosystems 63(1): 43-48.

[68] Zhang, L., Xu, M., Liu, Y., Zhang, F., Hodge, A., Feng, G. (2016): Carbon and phosphorus exchange may enable cooperation between an arbuscular mycorrhizal fungus and a phosphate-solubilizing bacterium. - New Phytologist 210(3): 1022-1032. 